DOI https://doi.org/10.30525/978-9934-26-073-5-2-74

\title{
ІНОЗЕМНА МОВА ЯК ЗАСІБ ФОРМУВАННЯ ПРОФЕСІЙНОЇ МОБІЛЬНОСТІ СТУДЕНТІВ ЕКОНОМІЧНИХ СПЕЦАЛЬНОСТЕЙ
}

\author{
Соколовська О. М. \\ кандидат філологічних наук, \\ дочент кафедри міжнародних економічних відносин \\ Центральноукраїнського національного технічного університету \\ м. Кропивницький, Україна
}

Однією 3 конкурентних переваг особистості в умовах глобального ринку праці вважають мобільність. IIÏ основні різновиди (соціальна, освітня, професійна та ін.) сприяють підвищенню ефективності розподілу трудових ресурсів. Визначальним фактором успішної діяльності спеціаліста у сучасному світі $є$ його професійна мобільність, яка зумовлює можливість адаптуватися у професійному середовищі, формує готовність до вирішення професійних завдань.

3-поміж багатьох чинників, які впливають на формування професійної мобільності, найбільш вагоме місце посідає освіта. Існує універсальна закономірність: чим вищий освітній потенціал, тим вища економічна активність, більша зайнятість, нижчий рівень безробіття. Професійній мобільності молоді сприяє ефективна взаємодія освітніх закладів із роботодавцями, гнучкість у визначенні змісту освіти з урахуванням зовнішніх факторів.

Знання іноземної мови підвищує конкурентоспроможність кандидата на ринку праці, сприяє міжнародній професійній мобільності. На думку більшості дослідників, компетентний, конкурентоспроможний випускник вищого навчального закладу повинен мати високий рівень знань 3 іноземної мови та вміти використовувати інформаційні технології [4, с.131].

Професійна мобільність студентів економічних спеціальностей - це інтеграція певних знань, умінь та навичок, що уможливлюють набуття та реалізацію активної професійної позиції майбутнього економіста. Зазначена сукупність включає усвідомлення можливостей професійної мобільності та професійного розвитку, володіння теоретичними знаннями у галузі економіки та інших фундаментальних наук. Крім того, необхідним видається комплекс умінь критично ставитися до інформації у мас-медіа, знаходити та раціонально використовувати професійно 272 
значиму інформацію, організовувати свою повсякденну навчальнопрофесійну діяльність, самостійно визначати та оперативно вирішувати проблемні завдання, швидко змінювати один вид навчальної діяльності на інший. Проте, пріоритетними залишаються навички ділового та професійного спілкування, роботи в колективі, опанування сучасних інформаційних та комунікаційних технологій, професійно-орієнтоване іншомовне усне та письмове спілкування.

Формування професійної мобільності спеціалістів економічного напряму вимагає перегляду традиційних підходів до навчання іноземної мови i організацію освітнього процесу таким чином, щоб засоби іноземної мови забезпечили майбутнього спеціаліста надійним мовним підгрунтям та були стимулом для майбутнього кар'єрного зростання.

Не викликає сумніву той факт, що основу глобалізації становлять інтеграційні процеси, що відбуваються на різних рівнях: від рівня окремих дисциплін до рівня загальнопрофесійної підготовки спеціалістів шляхом виокремлення головного у змісті кожної окремої дисципліни. Процес навчання повинен базуватися на розмежуванні дисциплін, посиленні спеціалізації та водночас інтеграції впродовж вивчення загального понятійного апарату з метою створення цілісної уяви про об’єкти, що вивчаються.

Сучасними науковцями встановлено, що впровадження інтегративного підходу у підготовці майбутніх економістів $\epsilon$ визначальним у процесі інтелектуалізації професійної підготовки [1;2] Для виконання практичних дослідницьких завдань інтегративний підхід $є$ домінуючим, оскільки він забезпечує формування мобільності завдяки поєднанню професійної підготовки та навчання іноземної мови. Одним із прикладів застосування інтеграції в навчальному процесі вважають іншомовну проектну діяльність, що дозволяє застосовувати набуті знання для вирішення конкретних професійних завдань.

Іноземна мова здатна зробити внесок у професійну підготовку майбутніх економістів шляхом вирішення студентами професійних завдань іноземною мовою, які відбивають інформаційну та комунікативну діяльність спеціаліста. У цьому випадку іноземна мова функціонує як засіб розвитку комунікативного компонента інформаційної культури студентів економічних спеціальностей у процесі здійснення ними пошукової та дослідницької діяльності у професійній сфері з використанням сучасних інформаційних технологій, участі в економічних on-line конференціях та проектах, розвитку навичок працювати в групі за посередництва мережі Інтернет. 
Розглядаючи іноземну мову як засіб розширення професійних знань та можливостей, видається доцільним звернути увагу на сучасні освітні технології навчання іноземних мов. Однією з таких технологій вважають предметно-мовне інтегроване навчання CLIL (Content and Language Integrated Learning).

CLIL розглядає навчання іноземної мови як засіб вивчення інших дисциплін, формуючи у студента потребу у навчанні, що дозволяє йому усвідомити та розвивати навички комунікації як іноземною, так і рідною мовами. У наукових дослідженнях сьогодення CLIL визначають як дидактичну методику, яка дозволяе сформувати у студента лінгвістичні та комунікативні компетенції іноземною мовою у тому ж навчальному контексті, в якому відбувається формування і розвиток загальнонавчальних знань та вмінь [5, с.69].

Практичний досвід використання зазначеної методики дає змогу виокремити низку позитивних рис, а також деякі проблеми втілення іiі у навчальний процес. Однією з переваг вважають підвищення мотивації студентів у вивченні іноземної мови. Вивчення мови набуває цілеспрямованого характеру, адже володіння нею виявляється необхідним для вирішення конкретних комунікативних завдань. Отже, вміння спілкуватися іноземною мовою у професійному контексті набуває пріоритетного значення у процесі здобуття вищої освіти. Крім того, студенти мають змогу краще зрозуміти культуру мови, яка вивчається, що призводить до формування соціокультурної компетенції майбутніх фахівців. 3-поміж основних перешкод для застосування методики CLIL у навчальному процесі найвагомішою видається відсутність у викладачів іноземної мови достатнього рівня знань 3 тієї чи іншої дисципліни i, навпаки, недосконале володіння іноземною мовою викладачів інших дисциплін.

Одним із можливих шляхів вирішення зазначеної проблеми $\epsilon$ підвищення рівня іншомовної компетенції науково-педагогічного складу вищих навчальних закладів.

У межах предметно-мовного інтегрованого навчання вагому роль відіграє викладач іноземної мови, діяльність якого спрямована на організацію міждисциплінарних зв'язків, застосування стратегії колегіальності з викладачами економічних та спеціальних дисциплін 3 метою використання вже на молодших курсах спеціальної економічної термінології, текстів, макетів документів. Участь самих студентів у процесі формування у них елементів професійної мобільності, окрім вивчення необхідного навчального матеріалу, полягає в активному прийнятті самої ідеї професійної готовності, що зумовлює володіння 
іноземною мовою. Окрім досконалого знання іноземної мови, CLIL вимагає проведення занять в абсолютно новому форматі. Викладач повинен використовувати різноманітні форми презентації матеріалу, організації роботи, роблячи акцент на індивідуальній та творчій діяльності студентів. Це означає, що вивчення спеціальних економічних дисциплін стане цікавішим та ефективнішим, за умови застосування діяльнісного та комунікативного підходів, притаманних заняттям 3 іноземної мови.

Таким чином, головною перевагою інноваційного навчання $\epsilon$ спрямованість на задоволення професійно-освітніх потреб студентів економічних спеціальностей, їх професійну мобільність та творче мислення. 3 методичного боку процес навчання грунтується на використанні варіативних навчальних програм, активних форм і методів навчання, особистісно-орієнтованого та диференційованого підходів.

\section{Література:}

1. Вайнтрауб М.А. Інтегроване розвивальне навчання у професійній школі. К.: Т. Клочко, 2009. 179 с.

2. Лузік Е.В. Інтегративний навчальний курс як теоретикометодологічна основа професійного становлення творчої особистості фахівця в системі вищої технічної освіти. Вісник Національного авіаиійного університету. Серія: Педагогіка, Психологія. 2010. № 3. C. 4-12

3. Міхненко Г.С. Генеза поняття «інтелектуальна мобільність фахівця». Рідна школа: Науково-педагогічний журнал. 2012. № 10(994). C. 17-22

4. Поленова А.Ю., Пшегусова Г.С. Иностранный язык как инструмент формирования профессиональной мобильности будущего экономиста. Journal of Economic Regulation (Bопросы регулирования экономики), 2015. T. 6 № 1. С 129-136

5. Coyle D., Hood P., Marsh D. CLIL: Content and Language Integrated Learning. Cambridge University Press, 2010. 184 p. 